CORRIGENDUM

\title{
Marking imprecision, conveying surprise: Like between hedging and mirativity
}

\author{
ANDREA BELTRAMA and EMILY A. HANINK \\ University of Konstanz
}

doi:10.1017/S0022226718000270, published online by Cambridge University Press, 6 August 2018.

In the Journal of Linguistics article 'Marking imprecision, conveying surprise: Like between hedging and mirativity' by Andrea Beltrama and Emily A. Hanink, a work by Ruth Maddeaux and Aaron Dinkin is cited incorrectly.

1. In Section 2.1 and in footnote 7, the citations 'Dinkin \& Maddeaux 2017' should read: Maddeaux \& Dinkin 2017

2. The corresponding entry in References should read:

Maddeaux, Ruth \& Aaron Dinkin. 2017. Is like like like? Evaluating the same variant across multiple variables. Linguistic Vanguard 3.1, 20150032.

\section{REFERENCE}

Beltrama, Andrea \& Emily A. Hanink. Marking imprecision, conveying surprise: Like between hedging and mirativity. Journal of Linguistics, doi:10.1017/S0022226718000270. Published online by Cambridge University Press, 6 August 2018. 